\title{
Composition and distribution patterns of marine planktonic ostracods (Crustacea, Ostracoda) in the Adriatic Sea - a historical perspective
}

\author{
Igor BRAUTOVIĆ ${ }^{1}$, Natalia BOJANIĆ2*, Olja VIDJAK², Branka GRBEC ${ }^{2}$ \\ and Barbara GANGAI ZOVKO ${ }^{1}$
}

${ }^{1}$ University of Dubrovnik, Institute for Marine and Coastal Research, Kneza Damjana Jude 12, 20000 Dubrovnik, Croatia

${ }^{2}$ Institute of Oceanography and Fisheries, Šetalište I. Meštrovića 63, 21000 Split, Croatia

"Corresponding author, e-mail: bojanic@izor.hr

\begin{abstract}
This study provides the first comprehensive results on species composition, seasonal and horizontal distribution of the planktonic ostracod community in the open waters of the whole Adriatic Sea. Samples were collected during the "Andrija Mohorovičić" oceanographic expedition (1974-1976) in all four seasons at 35 stations located along eight latitudinal transects in the northern, central and southern part of the Adriatic Sea. Fifteen ostracod species and two subspecies belonging to the family Halocyprididae were identified. The dominant species were Archiconchoecia striata, Porroecia spinirostris and Proceroecia macroprocera. Additionally, Paraconchoecia oblonga was recorded for the first time in the Adriatic Sea. The highest abundance and diversity of planktonic ostracods were found in the deep South Adriatic. Conversely, ostracods were scarce in the shallow North Adriatic area. As the transitional zone between these two regions, the Central Adriatic was characterized by high ostracod diversity, but a short period of dominance in the zooplankton assemblage. The horizontal distribution of planktonic ostracods in the Adriatic Sea could be linked to periodical ingressions of Eastern Mediterranean water masses and gyre currents, especially in the Central and the South Adriatic.
\end{abstract}

Key words: Halocyprididae, planktonic ostracods, community composition, distribution pattern, Adriatic Sea

\section{INTRODUCTION}

Planktonic ostracods are often neglected among mesozooplankton groups and consequently very little is known about their ecology, temporal variability or vertical distribution in most marine environments (ANGEL, 1993, 2010; GOLLASCH, 1997; BRAUTOVIĆ et al., 2006; ANGEL et al., 2007). Despite their diversity, abundance and noteworthy ecological role in the organic decomposition processes in deep waters, there is general scarcity of contemporary research and serious lack of taxonomic expertise for this group of planktonic crustaceans. The notable exceptions are the recent taxonomical investigations by CHAVTUR \& STOVBUN (2003), providing 
a review of the subfamily Archiconchoecinae, and by CHAVTUR \& ANGEL (2011), establishing two new tribes, the Metaconchoeciini and the Conchoeciini. The recent advances in molecular methods are offering a new tool for ostracod species' identification that, coupled with accurate identification based on external morphology, promises to contribute to scientific progress in the assessment of their role and importance (RAUPACH \& RADULOVICI, 2015; TANAKA \& OHTSUKA, 2016; NIGRO et al., 2016).

Since current biological expeditions rarely cover large marine areas, many authors revert to the planktonic material collected during earlier large-scale oceanographic expeditions (GRANATA \& DI CARPORIACCO, 1949; MORAITOUAPOSTOLOPOULOU, 1981; ANGEL, 1993; ANGEL et al., 2007), which offer both planktonic data and a historical perspective on the distribution and abundance of a particular taxon. One such opportunity was presented through the rich plankton material collected during the "Andrija Mohorovičić" oceanographic expedition (19741976), covering the entire Adriatic Sea and offering insight into the variability of the ostracod community during all four seasons.

From a historical point of view, research on planktonic ostracods in the Adriatic Sea began in the northern part at the end of the $19^{\text {th }}$ century, when Porroecia spinirostris was reported by CLAUS (1891). In the material collected during the "Rudolf Virchow" expedition (1907-1911), three new ostracod species, namely Proceroecia procera, Mikroconchoecia curta and Archiconchoecia striata, were determined by SCHWEIGER (1912). This author also considered their horizontal distribution and concluded that abundances decreased from the South to the North Adriatic. Later on, Conchoecia magna was recorded in the central part of the Adriatic Sea (GAMULIN, 1948; HURE, 1955, 1961). A few decades later, a new subspecies, Porroecia porrecta adriatica, was found in the North Adriatic (GOODAY \& ANGEL, 1977). Still, the highest number of new ostracod species in the Adriatic Sea was identified by BRAUTOVIĆ (1998), thus amending the list of species with Mikroconchoecia echinulata, Proceroecia microprocera, Proceroecia macroprocera, Discoconchoecia elegans, Metaconchoecia rotundata, Paraconchoecia spinifera, Loricoecia loricata and Paramollicia rhynchena. Recent investigations performed in the deep South Adriatic Pit have confirmed their presence in plankton and provided information of their spatial and temporal distribution (BRAUTOVIĆ et al., 2006).

The main purpose of this study was to determine the spatial and temporal distribution patterns of planktonic ostracods in the Adriatic Sea, using unpublished historical data collected at basin level during the "Andrija Mohorovičić" oceanographic expedition (1974-1976). The abundance and distribution of life-history stages (male, female and juvenile specimens) and the relationships with other mesozooplankton groups are also discussed. The paper also provides the first record of Paraconchoecia oblon$g a$ in the Adriatic Sea.

\section{MATERIAL AND METHODS}

\section{Oceanographical and biological properties of the Adriatic Sea}

The Adriatic Sea is one of the major regional sub-basins of the Mediterranean Sea, with a total surface of $132000 \mathrm{~km}^{2}$, average depth of $239 \mathrm{~m}$ and maximum depth of $1330 \mathrm{~m}$ (Fig. 1). It is approximately $800 \mathrm{~km}$ long and 200 $\mathrm{km}$ wide, oriented in the NW-SE direction. It is landlocked on the north; east and west side, and connected to the Ionian Sea on the south through the $72 \mathrm{~km}$ wide Strait of Otranto. The Adriatic basin is geomorphologically and hydrogeographically divided into three sub-basins: (I) the North Adriatic, a broad shallow area (on average $35 \mathrm{~m}$ deep), which lies entirely on the continental shelf, and is strongly influenced by the River Po; (II) the Central Adriatic, a shallow basin with a distinctive morphology in the form of three small bottom depressions or pits located along the transversal line of Šibenik-Pescara. The largest central depression is the Jabuka Pit, with a maximum depth of approximately $280 \mathrm{~m}$. The Central Adriatic is connected to the South Adriatic by the $170 \mathrm{~m}$ deep Palagruža sill; (III) 


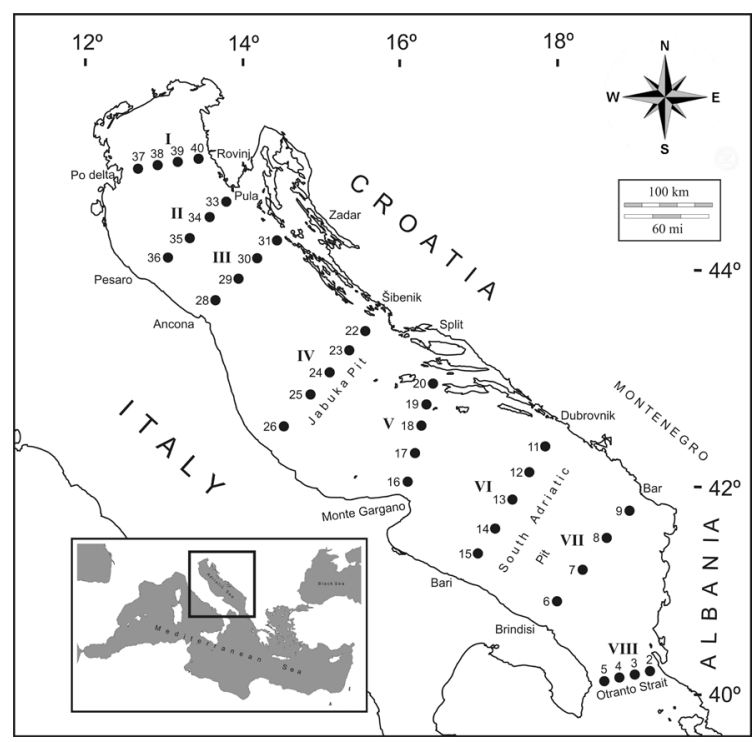

Fig. 1. Study area with the sampling stations located along eight transects.

the South Adriatic, mostly represented by the South Adriatic Pit, which is characterized by the approximately circular isobaths, with an average depth of about $1200 \mathrm{~m}$ in the central area. The bottom rises towards the Strait of Otranto past the southern basin, with the strait's maximum depth being $780 \mathrm{~m}$.

The general circulation model of the Adriatic Sea is characterized by the inflow of Ionian Surface Water and Levantine Intermediate Water northwards along the eastern coast, and a southward outflow into the eastern Mediterranean along the western coast (ORLIĆ et al., 1992). In the South Adriatic, surface circulation forms a gyre that partially isolates the Central Adriatic from the influence of open-sea Mediterranean waters, and strongly influences the distribution of Adriatic plankton communities (KRŠINIĆ \& GRBEC, 2002).

In the North Adriatic, the magnitude of phytoplankton development is positively related to increased nutrient load by the river Po, and gradually decreases in the SE direction (ZAVATARELLY et al., 1998; VILIČIĆ et al., 2009). The highest phytoplankton abundance and biomass are recorded just south of the river Po mouth (REVELANTE \& GILMARTIN, 1977). In the oligotrophic South Adriatic, the convective mixing and nutrient delivery into the surface layer in winter and spring precede phytoplankton blooms (VILIČIĆ et al., 1998; CIVITARESE \& GAČIĆ, 2001; GAČIĆ et al., 2002). After that period, thermal stratification, together with circular current maintenance and phytoplankton metabolic activity result in a gradual exhaustion of nutrients in the euphotic layer, and consequent decrease of phytoplankton biomass until the next spring (VILIČIĆ, 2003). In the warm part of the year, primary production of the South Adriatic in maintained, due to the microbial regeneration of nutrients within the microbial food web. Deeper Adriatic waters are characterised by chlorophyll $a$ and oxygen maxima in the layer between $50 \mathrm{~m}$ and $100 \mathrm{~m}$ depth as a result of the accumulation of microphytoplankton (JASPRICA et al., 2001).

The dominant microphytoplankton group in the Adriatic Sea are marine diatoms. The high abundances of dinoflagellates and cryptophytes occur occasionally in coastal environments, particularly in the North Adriatic Sea. Coccolithophores are coincidental with the inflow of Ionian waters, especially in the South Adriatic during winter (VILIČIĆ et al., 2002). Phytoplankton abundance data and chlorophyll $a$ concentrations from this expedition have been presented by SMODLAKA (1982).

Zooplankton are important phytoplankton predators in the surface layer and consume a significant portion of the available and usable primary production (KRŠINIĆ, 1998; VILIČIĆ, 2003). The estimates of zooplankton biomass in the Adriatic Sea indicate that rich zones are located in the northern Adriatic, along the western coast under the riverine influence and in few coastal bays along the eastern coast. In general, high zooplankton biomass is related to increased phytoplankton biomass, particularly in areas with river-borne nutrient loads. Both, microand mesozooplankton biomass decrease from the northern to the southern part of the Adriatic, while species richness generally increases in the same direction (FONDA UMANI et al, 1992). Biological data for mesozooplankton groups such as calycophoran siphonophores (GAMULIN, 1982a), copepods (HURE, 1982), euphausids (ŠIPOŠ, 1982), chaetognaths (GAMULIN, 1982b), appendicularians (SKARAMUCA, 1982) and thaliaceans 
(KATAVIĆ, 1982) during the investigation period have been published earlier (VUČAK et al., 1982).

\section{Thermohaline conditions during the sampling period}

Detailed physical and chemical data from "Andrija Mohorovičić" expedition are available in VUČAK et al. (1982). General distribution of thermohaline properties during the investigated periods was as follows:

September-October period (autumn) was characterized by surface temperature ranging from 18.5 to $22.0^{\circ} \mathrm{C}$, decreasing from the open South Adriatic toward the North Adriatic. Thermocline was formed between $10 \mathrm{~m}$ and $40 \mathrm{~m}$ depth in the northern and southern parts of the Adriatic Sea, respectively. Temperature minimum was recorded in the bottom layer of the Central Adriatic Jabuka Pit $\left(12^{\circ} \mathrm{C}\right)$. Surface salinity varied from 36.3 to 38.5 , with a noticeable increase from the coast to the open sea area and in north-south direction.

In February (winter), the highest surface temperature was recorded in the South Adriatic $\left(14^{\circ} \mathrm{C}\right)$. The temperature decreased transversally towards the North and towards the western coast, with the minimum of $9^{\circ} \mathrm{C}$ measured in the North Adriatic (T-I). The water column was generally isothermic, with the exception of the Northern Adriatic transects T-I and T-II where temperature inversion was recorded at the surface. Surface salinity was quite uniform throughout the area and ranged within the limits of 37.8 to 38.7 recorded at T-I and T-VII, respectively.

In April-May period (spring), surface temperature varied from $13.0^{\circ} \mathrm{C}$ to $19.5^{\circ} \mathrm{C}$, with both values recorded in the North Adriatic. In the Central and South Adriatic, both the freshwater generated by strong outflow of the Po River and the highly saline Mediterranean water were detected. The range of salinity values was between 23.6 and 38.8, recorded at T-I and T-VIII, respectively.

In July (summer), surface temperature increased in the North and the South Adriatic Sea to $24^{\circ} \mathrm{C}$ and $26^{\circ} \mathrm{C}$, respectively. Vertical temperature gradient was well pronounced and thermocline formed between $40 \mathrm{~m}$ and $80 \mathrm{~m}$ in the Central and South Adriatic, respectively. Surface salinity gradient was also established and values oscillated between 36.8 (T-I) and 38.5 (T-VII and T-VIII).

\section{Data collection}

Zooplankton material was collected during four cruises at 35 stations in the open Adriatic waters, by the research vessel "Andrija Mohorovičić" in the following periods: September-October 1974, April-May 1975, February and July 1976 (Fig. 1, Table 1). Twelve stations were sampled along three transects in the North Adriatic, with the station's depth ranging from 30 to $65 \mathrm{~m}$. Ten stations along two transects were sampled in the Central Adriatic (95 to $255 \mathrm{~m}$ ), and 13 stations were sampled along three transects in the South Adriatic (90 to $1100 \mathrm{~m}$ ).

Zooplankton was collected by vertical net hauls, from 5 to 10 meters above the sea bed to the surface using a Nansen net, $(113 \mathrm{~cm}$ diameter, $350 \mathrm{~cm}$ length, $250 \mu \mathrm{m}$ mesh size). Samples were fixed in $2.5 \%$ formaldehyde-seawater solution previously buffered with $\mathrm{CaCO}_{3}$. Species determination was performed by stereomicroscope (Carl Zeiss) and inverted microscope (Olympus IMT-2) at magnifications of 40x, 100x and 400x. Ostracods were identified according to species descriptions given by MÜLLER (1912), SKOGSBERG (1920), POULSEN (1973), ANGEL (1993) and DRAPUN \& SMITH (2012). The number of individuals was determined beneath the square meter (ind. $\mathrm{m}^{-2}$ ) of the water column.

\section{Data analysis}

The differences between the seasonal and spatial distribution of ostracod abundances were tested via two-way analysis of variance using Kruskal-Wallis statistics, followed by the post hoc Dunn's Multiple Comparison test. In order to avoid the effect of different sampling depths on the results, all data were recalculated to the same volume. The analyses were performed using the XLSTAT statistical package, Version 
Table 1. Geographic positions and depths of the investigated stations

\begin{tabular}{|c|c|c|c|}
\hline Transect & Station & Geographic position & Depth $[\mathrm{m}]$ \\
\hline \multicolumn{4}{|l|}{ NORTH ADRIATIC } \\
\hline \multirow[t]{4}{*}{ I Rovinj - Delta of the river Po (RdP) } & 40 & $45^{\circ} 05^{\prime} \mathrm{N} 13^{\circ} 31^{\prime} \mathrm{E}$ & 30 \\
\hline & 39 & $45^{\circ} 03^{\prime} \mathrm{N} 13^{\circ} 18^{\prime} \mathrm{E}$ & 30 \\
\hline & 38 & $45^{\circ} 01^{\prime} \mathrm{N} 13^{\circ} 04^{\prime} \mathrm{E}$ & 30 \\
\hline & 37 & $44^{\circ} 58^{\prime} \mathrm{N} 12^{\circ} 59^{\prime} \mathrm{E}$ & 30 \\
\hline \multirow{4}{*}{ II Pula - Pesaro (PP) } & 33 & $44^{\circ} 38^{\prime} \mathrm{N} 13^{\circ} 45^{\prime} \mathrm{E}$ & 30 \\
\hline & 34 & $44^{\circ} 28^{\prime} \mathrm{N} 13^{\circ} 30^{\prime} \mathrm{E}$ & 50 \\
\hline & 35 & $44^{\circ} 17^{\prime} \mathrm{N} 13^{\circ} 14^{\prime} \mathrm{E}$ & 50 \\
\hline & 36 & $44^{\circ} 09^{\prime} \mathrm{N} 12^{\circ} 59^{\prime} \mathrm{E}$ & 30 \\
\hline \multirow[t]{4}{*}{ III Zadar - Ancona (ZA) } & 31 & $44^{\circ} 15^{\prime} \mathrm{N} 14^{\circ} 29^{\prime} \mathrm{E}$ & 60 \\
\hline & 30 & $44^{\circ} 05^{\prime} \mathrm{N} 14^{\circ} 14^{\prime} \mathrm{E}$ & 60 \\
\hline & 29 & $43^{\circ} 54^{\prime} \mathrm{N} 13^{\circ} 59^{\prime} \mathrm{E}$ & 60 \\
\hline & 28 & $43^{\circ} 46^{\prime} \mathrm{N} 13^{\circ} 46^{\prime} \mathrm{E}$ & 60 \\
\hline \multicolumn{4}{|l|}{ CENTRAL ADRIATIC } \\
\hline \multirow{10}{*}{ V Split - Monte Gargano (SG) } & 22 & $43^{\circ} 32^{\prime} \mathrm{N} 15^{\circ} 32^{\prime} \mathrm{E}$ & 190 \\
\hline & 23 & $43^{\circ} 21^{\prime} \mathrm{N} 15^{\circ} 24^{\prime} \mathrm{E}$ & 200 \\
\hline & 24 & $43^{\circ} 06^{\prime} \mathrm{N} 15^{\circ} 08^{\prime} \mathrm{E}$ & 250 \\
\hline & 25 & $42^{\circ} 52^{\prime} \mathrm{N} 14^{\circ} 46^{\prime} \mathrm{E}$ & 250 \\
\hline & 26 & $42^{\circ} 35^{\prime} \mathrm{N} 14^{\circ} 28^{\prime} \mathrm{E}$ & 95 \\
\hline & 20 & $43^{\circ} 00^{\prime} \mathrm{N} 16^{\circ} 20^{\prime} \mathrm{E}$ & 100 \\
\hline & 19 & $42^{\circ} 46^{\prime} \mathrm{N} 16^{\circ} 17^{\prime} \mathrm{E}$ & 150 \\
\hline & 18 & $42^{\circ} 32^{\prime} \mathrm{N} 16^{\circ} 15^{\prime} \mathrm{E}$ & 150 \\
\hline & 17 & $42^{\circ} 19^{\prime} \mathrm{N} 16^{\circ} 12^{\prime} \mathrm{E}$ & 120 \\
\hline & 16 & $42^{\circ} 09^{\prime} \mathrm{N} 16^{\circ} 10^{\prime} \mathrm{E}$ & 100 \\
\hline \multicolumn{4}{|l|}{ SOUTH ADRIATIC } \\
\hline \multirow[t]{5}{*}{ VI Dubrovnik - Bari (DB) } & 11 & $42^{\circ} 33^{\prime} \mathrm{N} 17^{\circ} 55^{\prime} \mathrm{E}$ & 150 \\
\hline & 12 & $42^{\circ} 15^{\prime} \mathrm{N} 17^{\circ} 41^{\prime} \mathrm{E}$ & 1000 \\
\hline & 13 & $41^{\circ} 57^{\prime} \mathrm{N} 17^{\circ} 27^{\prime} \mathrm{E}$ & 1000 \\
\hline & 14 & $41^{\circ} 38^{\prime} \mathrm{N} 17^{\circ} 13^{\prime} \mathrm{E}$ & 800 \\
\hline & 15 & $41^{\circ} 20^{\prime} \mathrm{N} 17^{\circ} 00^{\prime} \mathrm{E}$ & 130 \\
\hline \multirow[t]{4}{*}{ VII Bar - Brindisi (BB) } & 9 & $41^{\circ} 49^{\prime} \mathrm{N} 19^{\circ} 02^{\prime} \mathrm{E}$ & 90 \\
\hline & 8 & $41^{\circ} 28^{\prime} \mathrm{N} 18^{\circ} 43^{\prime} \mathrm{E}$ & 480 \\
\hline & 7 & $41^{\circ} 09^{\prime} \mathrm{N} 18^{\circ} 26^{\prime} \mathrm{E}$ & 1000 \\
\hline & 6 & $40^{\circ} 51^{\prime} \mathrm{N} 18^{\circ} 08^{\prime} \mathrm{E}$ & 140 \\
\hline \multirow[t]{4}{*}{ VIII Otranto Strait (OS) } & 2 & $44^{\circ} 04^{\prime} \mathrm{N} 19^{\circ} 16^{\prime} \mathrm{E}$ & 1000 \\
\hline & 3 & $40^{\circ} 04^{\prime} \mathrm{N} 19^{\circ} 12^{\prime} \mathrm{E}$ & 900 \\
\hline & 4 & $40^{\circ} 06^{\prime} \mathrm{N} 18^{\circ} 56^{\prime} \mathrm{E}$ & 800 \\
\hline & 5 & $40^{\circ} 06^{\prime} \mathrm{N} 18^{\circ} 46^{\prime} \mathrm{E}$ & 600 \\
\hline
\end{tabular}

2015.4.01.21575, Copyright Addinsoft 19952017.

Non-parametric Spearman rank order correlations were used to assess the relationships between ostracods and other mesozooplankton groups.
Cumulative ranked curves (k-dominance curves) were used to compare species dominance along the investigated transects. K-dominance curves were plotted on the cumulative ranking of ostracod species in order of importance in terms of their abundance. 
The Shannon-Wiener diversity index ( $\left.\mathrm{H}^{\prime}\right)$ was used to analyse changes in seasonal and spatial diversity in the ostracod community. Since the juvenile species were determined to genus level, they were included in the species data matrix.

BVSTEP analysis was performed on the ostracod species data in order to find a combination of species explaining all differences within the species matrix, and to produce a near perfect match $(\rho \geq 0.95)$ with the overall seasonal and spatial pattern for the full set of ostracod species.

To show the contribution of ostracod taxa to the dissimilarities among the sampling areas, similarity percentages analysis (SIMPER) was performed on the $\log (\mathrm{x}+1)$ transformed abundance data matrix, with the cut-off for low contributions fixed at $90 \%$. This analysis identified ostracod taxa that were principally responsible for the sample grouping in the ordination analysis.

Non-metric Multi-Dimensional Scaling (MDS) ordination and Cluster Analysis (CA) were used to investigate similarity levels of species abundances along different transects. To reveal similarities between stations, the abundance data matrix was standardized, then log $(\mathrm{x}+1)$ transformed and Bray-Curtis similarity was computed. These analyses were performed using the Primer 5 version 5.2.9 (CLARKE \& GORLEY, 2001) statistical package. Principal Component Analysis (PCA) was performed to summarise the main patterns of species/groups composition variation across samples. The data input consisted of two sets of variables representing spatial and seasonal abundances of (I) all ostracod species and (II) most abundant mesozooplankton groups (Ostracoda, Copepoda, Siphonophorae, Euphausiida, Chaetognatha, Appendicularia and Thaliacea). Each ostracod species or mesozooplankton group points in the direction of the steepest increase in abundance for corresponding variable and its length is the multiple correlation of that species/mesozooplankton group with the ordination axes. On the other hand, the distance between sample symbols (season, transect) approximates the dissimilarity of their species/group composi- tion as measured by their Euclidean distance (TER BRAAK \& ŠMILAUER, 2012). The analysis was performed using the XLSTAT, Version 2015.4.01.21575, statistical package, Copyright Addinsoft 1995-2017.

\section{RESULTS}

\section{Spatial and seasonal variability of Adriatic ostracods}

During four cruises, planktonic ostracods were present throughout the Adriatic Sea, but their spatial distribution showed considerable variability (Kruskal-Wallis statistics: $\mathrm{K}=83.950$; $\mathrm{p}<0.0001)$. The highest average abundance of total ostracods $\left(1080 \pm 842\right.$ ind. $\left.\mathrm{m}^{-2}\right)$ was recorded in the deep South Adriatic, with a maximum of 4021 ind. $\mathrm{m}^{-2}$ (Fig. 2). Towards the north, their abundances decreased considerably. In the Central Adriatic, the average abundance, as well as the recorded maximum was reduced to approximately half of that value $\left(597 \pm 615\right.$ ind. ${ }^{-}$ 2 and 2412 ind. $\mathrm{m}^{-2}$, respectively). Ostracods were scarce in the North Adriatic, where either few individuals or even their complete absence

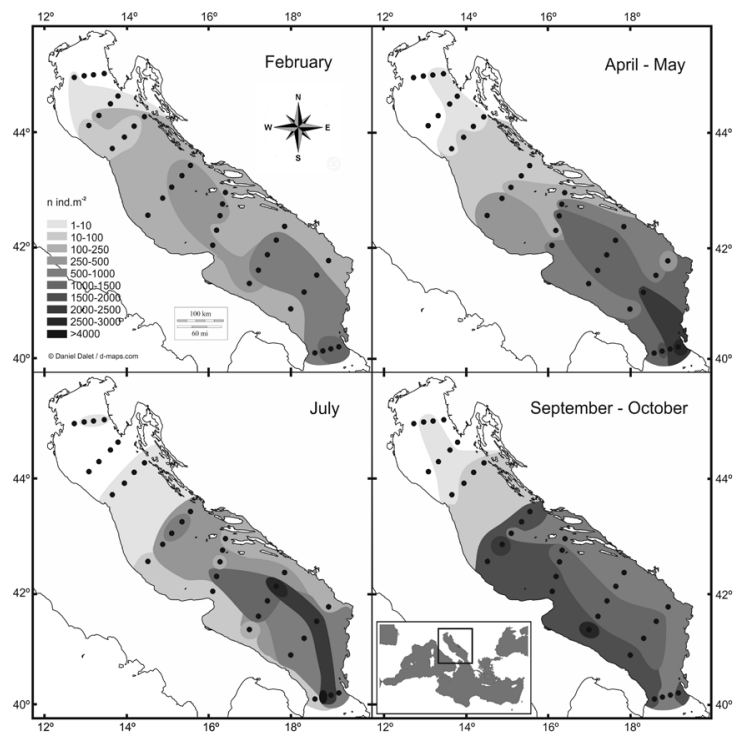

Fig. 2. Spatial and seasonal distribution of total planktonic ostracods during the four seasons: autumn (September - October 1974), spring (April - May 1975), winter (February 1976) and summer (June 1976) in the Adriatic Sea. 
were noticed. The annual average and maximum values in this region were $11 \pm 26$ ind. $\mathrm{m}^{-2}$ and 114 ind. $\mathrm{m}^{-2}$, respectively.

At basin level, temporal variability of total ostracod abundances did not show a clear seasonal pattern $(\mathrm{K}=4.225 ; \mathrm{p}=0.238)$. Therefore, seasonal variability should be considered only in relation to the Adriatic sub-basins. During most of the year, the highest abundances were recorded in the open waters of the South and Central Adriatic Sea (Fig. 2). A total annual maximum of 4021 ind. $\mathrm{m}^{-2}$ (1041 female ind. $\mathrm{m}^{-2}$, 906 male ind. $\mathrm{m}^{-2}$ and 2074 juvenile ind. $\mathrm{m}^{-2}$ ) was recorded in the summer at station 4 in the Strait of Otranto (Transect: T-VIII, Fig. 1). Very high abundances continued towards the Central Adriatic (T-IV and $\mathrm{T}-\mathrm{V}$ ). During the autumn, the highest value was found in the area of Jabuka Pit and along the western coast of the Central and South Adriatic, and proportionally decreased towards the eastern coast. The autumn maximum of 2846 ind. $m^{-2}$ (776 female ind. $m^{-2}$, 756 male ind. $m^{-2}$ and 1314 juvenile ind. $\mathrm{m}^{-2}$ ) was found at station 15 in the South Adriatic Bari Canyon (T-VI). Conversely, in the winter period, a decrease in overall ostracod abundances caused quite uniform distribution in the South and Central Adriatic, while the North Adriatic area differed significantly $(K=10.343 ; p=0.006)$. In this (the North Adriatic) area, the annual maximum of 114 ind. $m^{-2}$ (41 female ind. $m^{-2}, 40$ male ind. $m^{-2}$ and 33 juvenile ind. $\mathrm{m}^{-2}$ ) was noticed at station 31 (T-III).

A

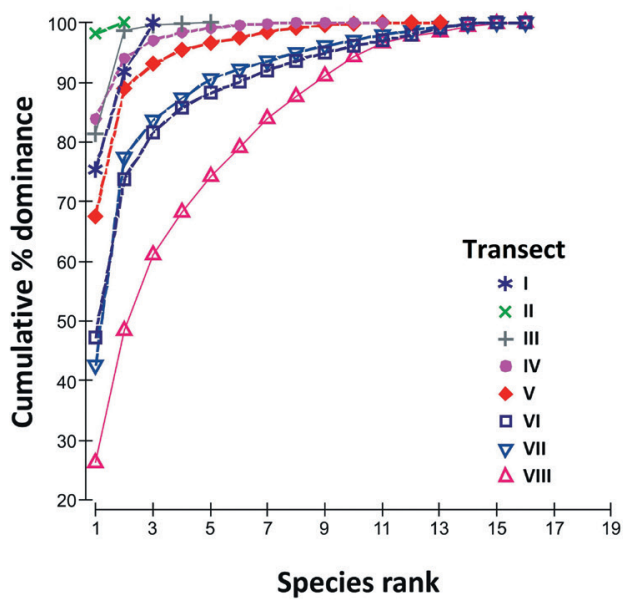

The proportion varied significantly per lifehistory stage and season $(\mathrm{K}=9.835 ; \mathrm{p}=0.020)$. Juvenile specimens constituted between $46.17 \%$ in autumn and $61.58 \%$ in winter of the ostracod community. The largest proportion of juveniles (92\%) was recorded in the South Adriatic Sea. In this part of the Adriatic Sea, their highest proportion $(70.65 \%)$ was recorded in winter, while in the Central Adriatic the highest contribution of juveniles to the ostracod community was found in autumn (65.63\%). During other seasons, the share of juveniles in the ostracod community decreased, with the lowest values recorded in the northern Adriatic during the summer.

\section{Species composition and diversity patterns in the ostracod community}

A total of sixteen taxa of planktonic ostracods belonging to family Halocyprididae, two subfamilies, 10 genera and including two subspecies were identified during this study (Table $2)$. The South Adriatic was the only area where all 16 taxa were recorded (T-VI-VIII). The taxonomic variety was slightly lower (11-13 taxa) in the Central Adriatic, while only 2 species were found in the North Adriatic (T-II). K-dominance curves allowed a better comparison of differences in ostracod diversity between the investigated transects (Fig. 3). The highest curve, showing the lowest diversity, was at T-II in the North Adriatic. A $>90 \%$ dominance was

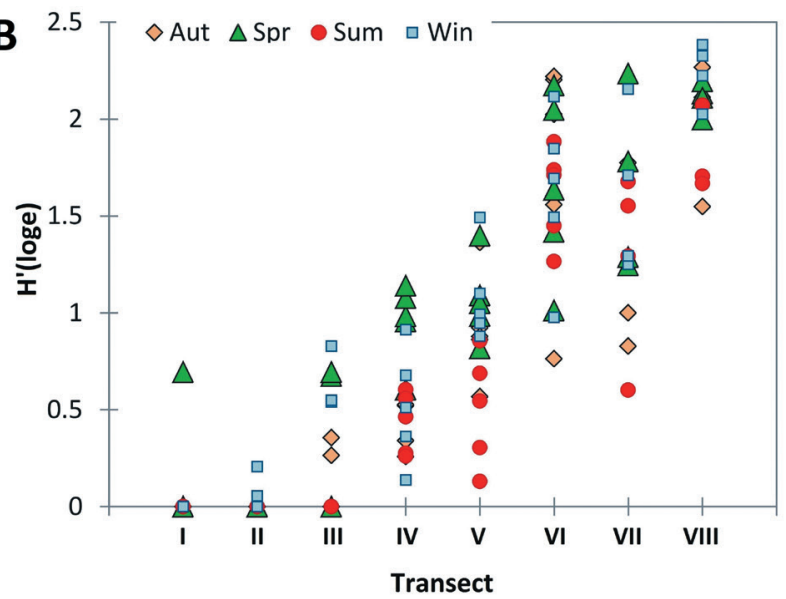

Fig. 3. K-dominance curves of ostracod species (A) and seasonal variability of Shannon-Wiener (H') biodiversity index (B) in the Adriatic Sea. 
Table 2. List of the registered ostracod taxa in the Adriatic Sea and frequencies of occurrence in the samples. $(+$, presence; blank, absence)

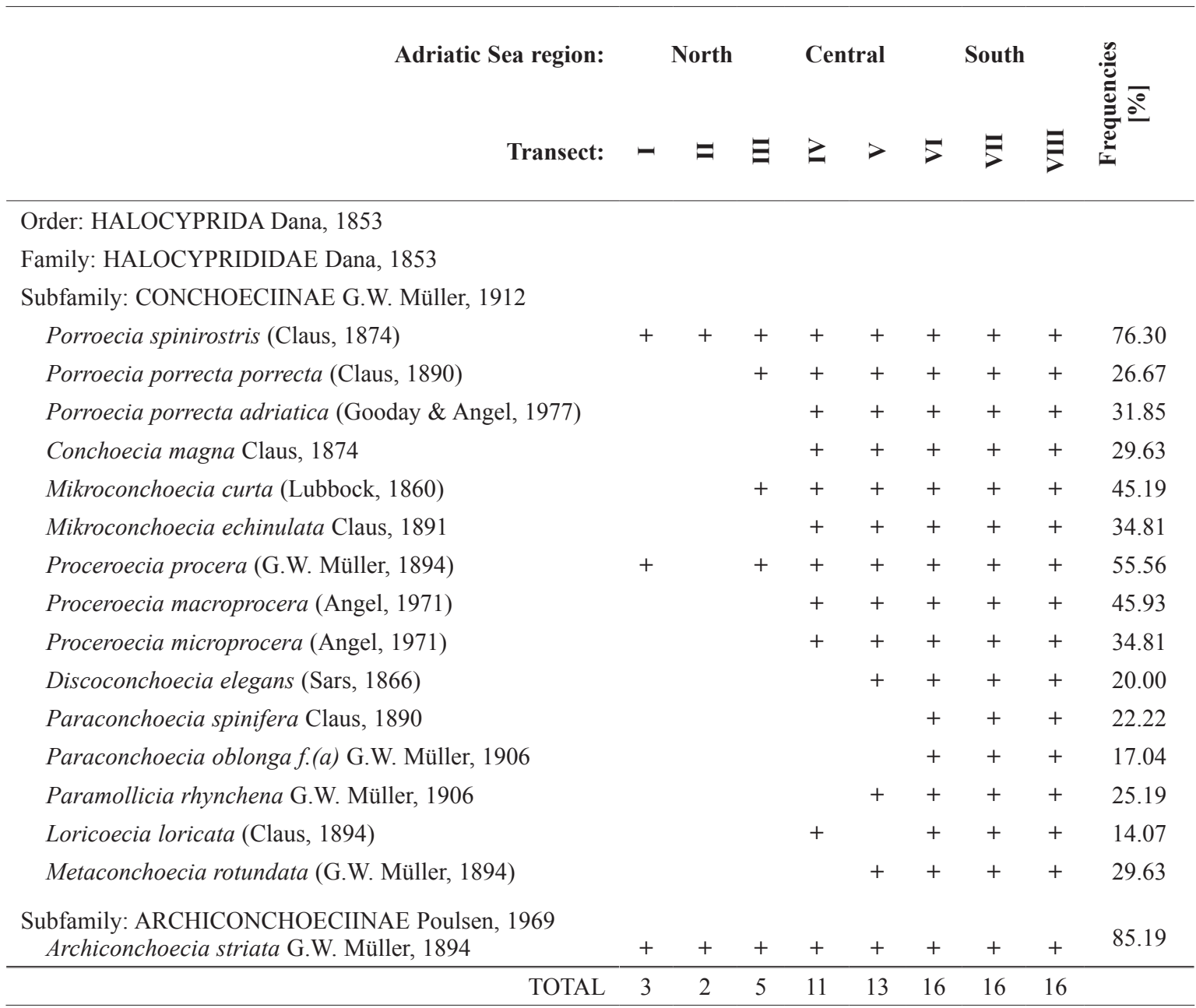

found along transects T-I, T-II and T-III for species rank 2. Conversely, the highest biodiversity was recorded along three transects in the South Adriatic, especially at T-VIII (Otranto Strait). In this area, a $>90 \%$ dominance was reached for species rank 6 or higher (Fig. 3A). At seasonal level, the highest biodiversity was recorded during the spring.

Based on their contribution to total ostracod abundances, the dominant species were Archiconchoecia striata, Porroecia spinirostris and Proceroecia macroprocera, which together contributed $57.13 \%$ to the total ostracod population. According to the SIMPER results, the same group of species was responsible for the average dissimilarity of $61.45 \%$ found between the South and Central Adriatic Sea (at $66.97 \%$ level). The highest average dissimilarity of $90.41 \%$ was recorded between the South and North Adriatic (at $63.93 \%$ level). Cross-comparison of ostracod populations during the sampling seasons did not reveal differences in population structure.

The variability in the Shannon-Wiener diversity index $\left(H^{\prime}\right)$ revealed the significant differences between the three Adriatic sub-basins $(\mathrm{K}=112.79 ; \mathrm{P}<0.0001)$, with the highest average $\mathrm{H}^{\prime}$ of $2.06 \pm 0.24$ found at T-VIII in the South Adriatic Sea and the lowest H' of $0.02 \pm 0.05$ recorded at T-II in the North Adriatic (Fig. 3B). Overall, the maximum H' value was found at T-VIII (South Adriatic) during the winter (2.38). At seasonal scale, we noticed a high homo- 


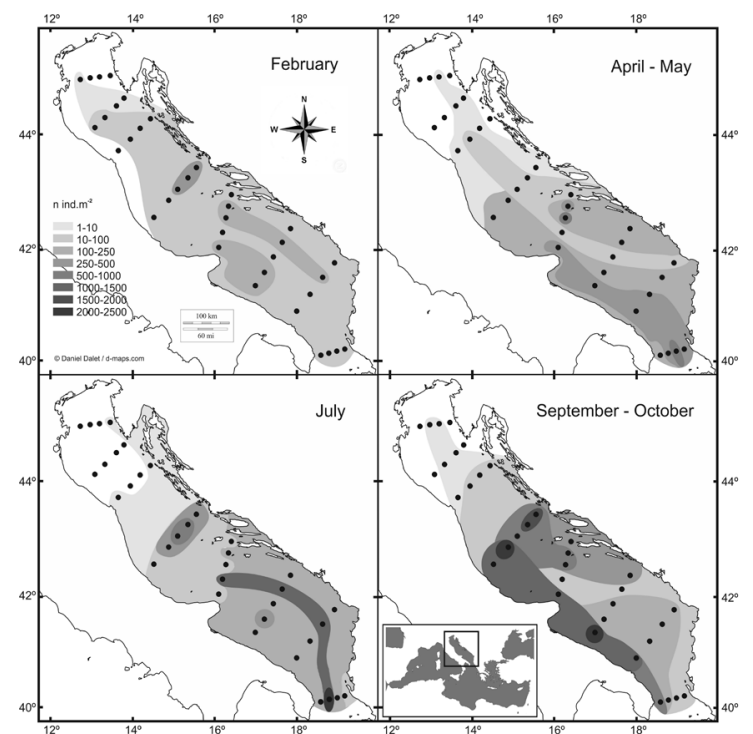

Fig. 4. Spatial and seasonal distribution of Archiconchoecia striata during the four seasons: autumn (September - October 1974), spring (April - May 1975), winter (February 1976) and summer (June 1976) in the Adriatic Sea.

geneity in ostracod community composition, without statistically significant differences in $H^{\prime}$ between seasons $(K=5.66$; $p=0.129)$. Species richness, expressed as a number of ostracod species (S), was positively and significantly related to overall abundance $(\mathrm{N})$ on both the spatial and seasonal scale (Spearman statistics $\mathrm{p}<0.01)$. Negative relations were recorded only in the South Adriatic along transects T-VI and T-VII. Ostracod abundance (N) was positively correlated with the $\mathrm{H}^{\prime}$ index at transects I-III and $\mathrm{T}-\mathrm{V}$, while these correlations were negative at transects IV, VI-VIII. However, statistically significant relations $(\mathrm{p}<0.01 \%)$ were found only at T-VI and T-VIII.

The most frequent planktonic ostracod species occurring in $>56 \%$ of collected samples were Archiconchoecia striata, Porroecia spinirostris and Proceroecia procera (Table 2). The lowest frequencies of occurrence were recorded for Paraconchoecia oblonga and Loricoecia loricata ( $17 \%$ and $14 \%$, respectively). All other taxa can be considered as common. The application of the BVSTEP procedure to the sixteen ostracod taxa abundances extracted the smallest subset of five species. Their similarity matrices across eight transects correlated with that of the full list of recorded taxa, at $\rho=0.996$ and significance level of 0.01 . This subset was responsible for generating the observed distribution pattern and consisted of Archiconchoecia striata, Porroecia spinirostris, Proceroecia macroprocera, Discoconchoecia elegans and Mikroconchoecia curta.

Archiconchoecia striata was recorded throughout the Adriatic during all seasons (Fig. 4) and constituted $43.85 \%$ of the ostracods. During the winter and summer periods, this species was most abundant in the waters of the Central and South Adriatic, while in spring and autumn it concentrated at the stations closer to the coast. The highest total abundance of 2294 ind. $\mathrm{m}^{-2}$ (660 female ind. $\mathrm{m}^{-2}$, 636 male ind. $\mathrm{m}^{-2}$ and 998 juvenile ind. $\mathrm{m}^{-2}$ ) was found in autumn at T-VI (station 15). This autumn increase in $A$. striata abundances was caused by adult individuals, while juveniles dominated in the winter period with up to $75 \%$ (T-VII, station 8). Due to its high contribution to total abundances, the spatial distribution pattern of ostracods during all seasons was highly related to $A$. striata distribution. Figs. 2, 3 and 4 distinguished the Central Adriatic Jabuka Pit (T-IV) as the area very abundant in ostracods and rich in ostracod species.

Porroecia spinirostris constituted $21.36 \%$ of the ostracods. Although this species was recorded throughout the Adriatic Sea, it was distributed unevenly between the Adriatic sub-basins (Fig. 5). The highest abundances were always recorded in the South Adriatic, with the values being 5 to 8 times higher than in the Central Adriatic. Conversely, the species was rare in the North Adriatic. The maximum of 583 ind. $\mathrm{m}^{-2}$ (174 female ind. $\mathrm{m}^{-2}, 179$ male ind. $\mathrm{m}^{-2}$ and 230 juvenile ind. $\mathrm{m}^{-2}$ ) was recorded in the summer at T-VIII (station 4). The highest proportion of juveniles $(61 \%)$ was observed in spring at T-VI (station 15).

Proceroecia macroprocera constituted $9.44 \%$ of the ostracods. This species was found only in the Central and South Adriatic (Fig. 6). In the Central Adriatic, a slightly higher number of individuals $\left(\sim 100\right.$ ind. $\left.\mathrm{m}^{-2}\right)$ was recorded only in autumn at $\mathrm{T}-\mathrm{V}$, while during the other seasons this species was sporadically represented by 


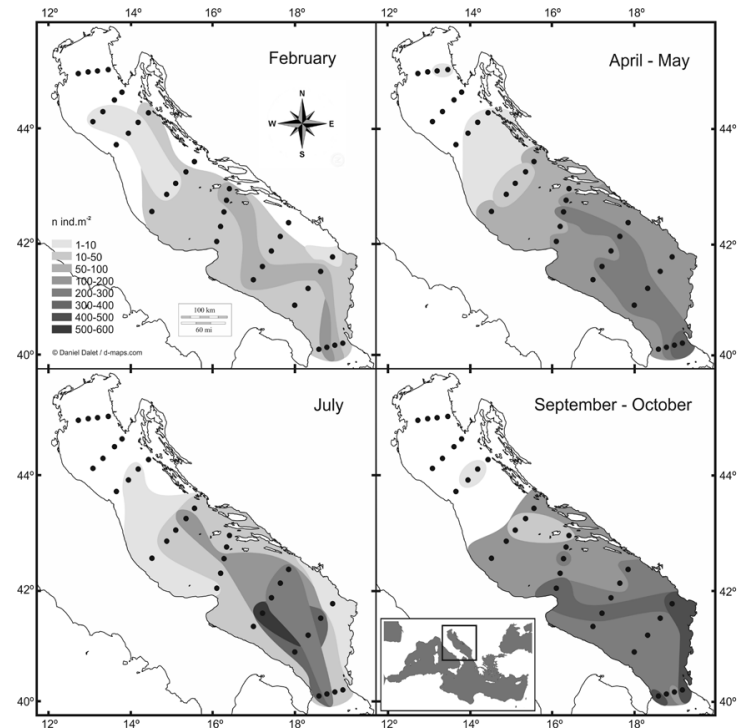

Fig. 5. Spatial and seasonal distribution of Porroecia spinirostris during the four seasons: autumn (September - October 1974), spring (April - May 1975), winter (February 1976) and summer (June 1976) in the Adriatic Sea.

few specimens. In the South Adriatic, notably higher abundances in comparison to the Central Adriatic were found. The maxima were recorded at T-VIII (station 2) and T-VII (station 7) during the spring, with the abundances being 510 ind. $m^{-2}$ (132 female ind. $m^{-2}$, 128 male ind. $m^{-2}$ and 250 juvenile ind. $\mathrm{m}^{-2}$ ) and 570 ind. $\mathrm{m}^{-2}$ (96 female ind. $\mathrm{m}^{-2}, 86$ male ind. $\mathrm{m}^{-2}$ and 388 juvenile ind. $\mathrm{m}^{-2}$ ), respectively. The lowest abundances were recorded in the winter period. The proportion of juveniles in the population of $P$. macroprocera usually exceeded $68 \%$.

Discoconchoecia elegans represented 2.85\% of total planktonic ostracods. This species was mostly restricted to the South Adriatic except in autumn when it was recorded in the Central Adriatic as well (T-V, station 18). The highest abundances of 312 ind. $\mathrm{m}^{-2}$ (59 female ind. $\mathrm{m}^{-2}$, 84 male ind. $\mathrm{m}^{-2}$ and 169 juvenile ind. $\mathrm{m}^{-2}$ ) were recorded in the summer at T-VIII (station 4). During the summer period, juveniles reached the highest contribution $(\sim 60 \%)$ at T-VI (station 12$)$.

Mikroconchoecia curta constituted $2.60 \%$ of ostracods, and spatial distribution was mostly restricted to the South and Central Adriatic. Females were more abundant than males by

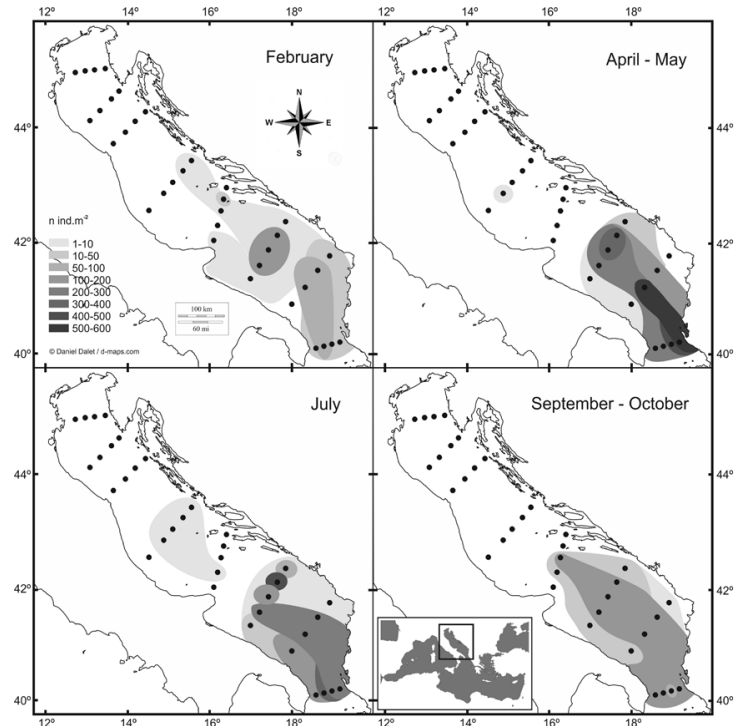

Fig. 6. Spatial and seasonal distribution of Proceroecia macroprocera during the four seasons: autumn (September - October 1974), spring (April - May 1975), winter (February 1976) and summer (June 1976) in the Adriatic Sea.

approximately $30 \%$, but the abundance of juveniles was four times higher than that of adults, especially during the summer (up to $87 \%$ ). The maximum of 206 ind. $m^{-2}$ (21 female ind. $m^{-2}$, 27 male ind. $\mathrm{m}^{-2}$ and 158 juvenile ind. $\mathrm{m}^{-2}$ ) was found in autumn at T-VIII (station 2). In autumn and spring, at T-VIII, the abundances increased mostly due to juveniles. In the Central Adriatic, the species was considerably less represented in the ostracod community, with a maximum of 32 ind. $\mathrm{m}^{-2}$ ( 8 female ind. $\mathrm{m}^{-2}$ and 24 juvenile ind. $\mathrm{m}^{-}$ $\left.{ }^{2}\right)$ recorded during spring at T-V (station 19).

The newly recorded ostracod species Paraconchoecia oblonga was restricted to the South Adriatic, and its contribution to the total number of planktonic ostracods was negligible $(0.51 \%)$. A maximum of 60 ind. $\mathrm{m}^{-2}$ (4 female ind. $\mathrm{m}^{-2}, 4$ male ind. $\mathrm{m}^{-2}$ and 52 juvenile ind. $\mathrm{m}^{-}$ $\left.{ }^{2}\right)$ was recorded in winter at T-VII (station 7), when juveniles constituted $87 \%$ of the population of this species. Compared to juveniles, the adults were considerably less abundant, with the highest values of 12 female ind. $\mathrm{m}^{-2}$ and 6 male ind. $\mathrm{m}^{-2}$ found in spring at T-VI (station 13). 


\section{Multivariate data analyses}

\section{Ostracod community}

From the resulting multivariate data analysis (Multi Dimensional Scaling and Cluster Analysis) based on ostracod species abundances, we distinguished two main groups of investigated stations separated at $44.40 \%$ similarity level ( $\pi=8.22 \mathrm{p}=0.001)$ (Fig. 7). The first cluster comprised stations located in the South Adriatic. The second cluster contained two subgroups, divided at similarity level of $59.87 \%(\pi=2.37$, $\mathrm{p}=0.001$ ); the first subgroup included only stations located in the North Adriatic while the second encompassed stations from the Central and North Adriatic. The differences between them were statistically significant; $72.94 \%$ similarity $(\pi=1.70, \mathrm{p}<0.001)$.

The patterns of spatial and seasonal variability in species abundance, diversity indicators, transects, seasons and sampling depths, were examined by means of Principal Component Analysis (Fig. 8). This analysis ordinated group with similar patterns of spatial and seasonal variability along three axes, explaining $73.05 \%$ of total variability. Transects linked to the same axes are given in parenthesis. Axis PC1 $(48.33 \%)$ determined the variability of the following 12 ostracod species: P. macroprocera, $C$. magna, $M$. rotundata, $P$. spinifera, $P$. rhynchena, P. microprocera, M. curta, P. oblonga, D. ele-



Fig. 7. Non-metric multidimensional scaling (MDS) ordination of eight sampling transects (each dot corresponds to a sampling station) in the Adriatic Sea, based on Bray Curtis similarities from standardised and log transformed ostracod species abundances (see Table 2 for the list of ostracod taxa).

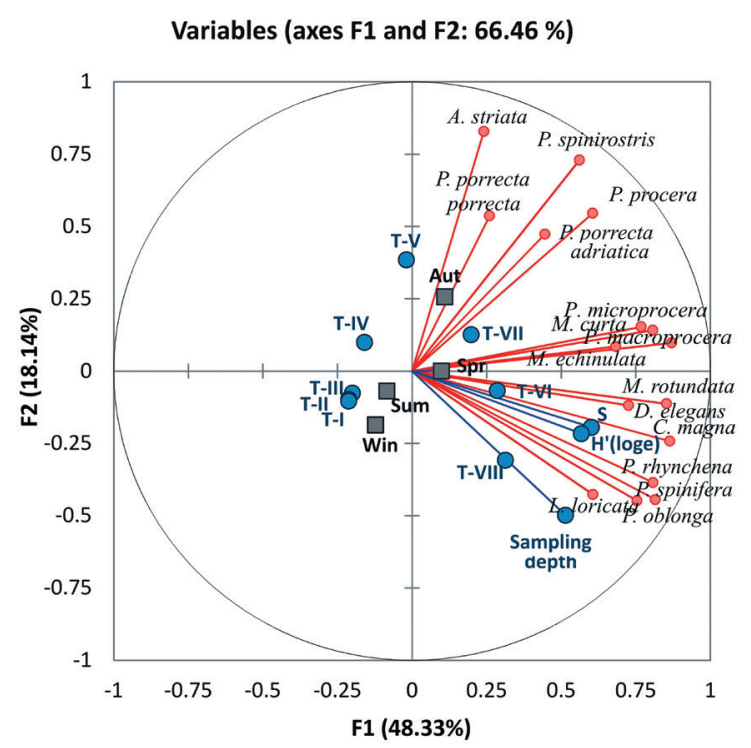

Fig. 8. Results of Principal Component Analysis (PCA) based on abundance data matrix of planktonic ostracod taxa. Supplementary variables (quantitative and qualitative) are plotted as vectors or dots (circles, transects; rectangles, sampling seasons).

gans, M. echinulata, L. loricata and P. procera (T-VIII, T-VI and T VII). Axis PC2 (18.14\%) ordinated the two most abundant species $A$. striata and $P$. spinirostris, and a subspecies P. porrecta adriatica (T-V and T-VII). PC3 (6.58\%) included subspecies $P$. porrecta porrecta. Among the supplementary variables (seasons, sampling depths, number of species (S) and Shannon-Wiener diversity index (H')), PC1 was significantly positively related to sampling depth, S and H'. PC2 was negatively linked to sampling depth, $\mathrm{S}$ and $\mathrm{H}^{\prime}$, but the significant relationship was recorded only with sampling depth. Relationships between PC axes and seasons were less pronounced. PC1 was not clearly related to any sampling period, while the PC2 and PC3 axes clustered autumn period.

\section{Other mesozooplankton groups}

Apart from the abundance of ostracods, the abundances of other main mesozooplankton groups (siphonophores, copepods, euphausids, chaetognaths, appendicularians and thaliaceans) were included in the data matrix for PCA. 


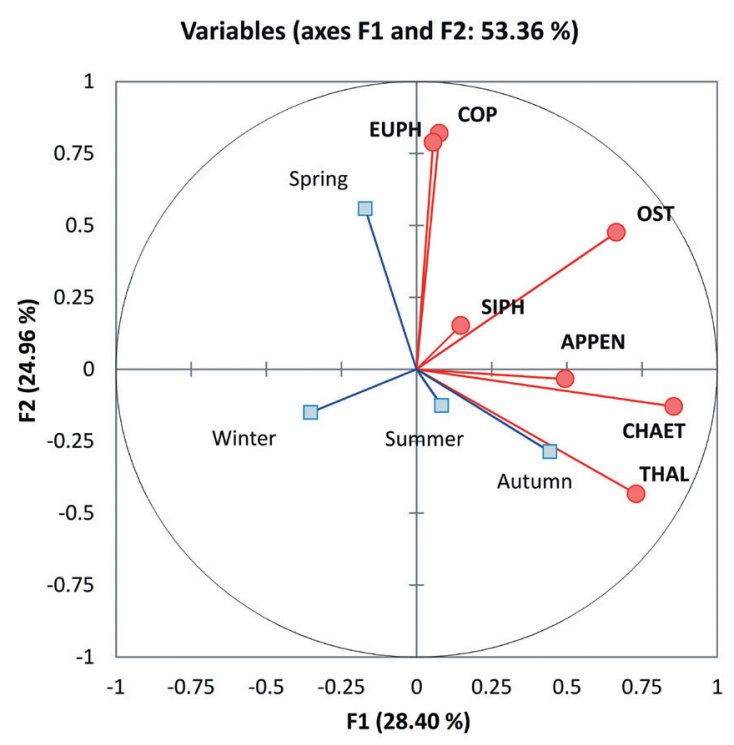

Fig. 9. Ordering of mesozooplankton groups with respect to their abundances obtained by the Principal Component Analysis (PCA). Suplemantary nominal variable (sampling season) is plotted as rectangles. (OST, Ostracoda; SIPH, Siphonophora; COP, Copepoda; EUPH, Euphasiacea; CHAET, Chaetognatha; APPEN, Appendicularia and THAL, Thaliacea)

The analysis extracted three principal components, accounting for $72.08 \%$ of variance (Fig. 9). PC1 separated ostracods, chaetognaths and thaliaceans, explaining $28.40 \%$ of variance. PC2 extracted copepods and euphausids, while PC3 differenciated siphonophores and appendicularians. The last two components explained $24.96 \%$ and $18.72 \%$ of variance, respectively. Similar variability of different mesozooplankton groups, indicated by the statistically significant correlations, could result from either predatorprey relationship (ostracods with chaetognaths and siphonophorae) or co-linearity (ostracods with copepods, appendicularians and thaliaceans) within the mesozooplankton community (Figs. 2 and 9). As opposed to ostracods, a clear seasonal distribution pattern was recorded for copepods and euphausids that reached a maximum in spring. On the other hand, chaetognaths, thaliaceans and appendicularians were the most abundant in autumn.

\section{DISCUSSION}

\section{Seasonal and spatial distribution of ostracod species}

The highest abundance of planktonic ostracods during all seasons was found in the deep South Adriatic. In general, the decreases in ostracod abundances in the south-east and north-west directions was noticed in the Central Adriatic, where the abundance values were often ten times lower than in the South Adriatic. We concluded that the distribution of ostracods in the Adriatic Sea, especially during spring and summer, is influenced by basin hydrology. Adriatic circulation is characterized by the incoming current from the Eastern Mediterranean in the intermediate layer, while Adriatic waters enter the Mediterranean in the surface and bottom layers (ORLIĆ et al., 1992; CUSHMAN-ROISIN \& POULAIN, 2001). The surface and intermediate waters from the Central Adriatic differ from the dense bottom water that is formed during winter in the shallow North Adriatic, which fills the bottom of the Jabuka Pit (ZORE-ARMANDA, 1963). The Jabuka Pit is a storage area for this bottom water that is occasionally pushed out and moved to the south Adriatic (ORLIĆ et al., 1992). This cold dense water, rich in detritus, sinks in the region of the Bari Canyon and flows out of the Adriatic Sea (VILIBIĆ \& ORLIĆ, 2001). This circulation pattern could explain the considerably higher ostracod abundances observed in the summer in the central part of the South Adriatic and at the stations located along the western Adriatic coast in autumn. Our investigation indicated that the Jabuka Pit (T-IV) and the South Adriatic Sea (especially T-VI) are the most important areas for studying the population dynamics of planktonic ostracods. The crucial significance of the dynamics of water masses for the spatial and seasonal distribution of zooplankton populations was also recorded by KRŠINIĆ \& GRBEC (2002, 2006).

The seasonal and spatial distribution of lifehistory stages throughout the Adriatic Sea indicates that for ostracods, autumn and winter represent the reproduction period, and points to the Central and especially South Adriatic as 
the areas that provide multiple habitats for the development of ostracod populations.

The highest diversity of ostracods was recorded in the deep South Adriatic. In the Central Adriatic, due to smaller depths, deep-sea species such as Paraconchoecia oblonga, P. spinifera and Paramollicia rhynchena were absent, and the mesopelagic species Conchoecia magna, Proceroecia macroprocera, Metaconchoecia rotundata, Discoconchoecia elegans and Loricoecia loricata were rare. Furthermore, the shallow North Adriatic generally showed the lowest ostracod diversity. The key species were Archiconchoecia striata and Porroecia spinirostris, very common in the epipelagic and upper mesopelagic layers of the entire Adriatic Sea. Proceroecia macroprocera ranked third in abundance, and was distributed in the South and Central Adriatic. On the basis of the distribution of PC loadings, those three species were responsible for most of the observed variability in the ostracod population.

In an earlier investigation GOODAY \& ANGEL (1977) registered five ostracod species in the North Adriatic. Apart from A. striata, P. spinirostris and $P$. procera, they found $P$. porrecta adriatica and $M$. echinulata. Similar to our results, they recorded the maximum of total ostracod abundance in the winter. The spreading of ostracods from the Central towards the North Adriatic from December to April was first observed by STEUER (1910). Similar taxonomical composition and proportions of ostracod species in the Central and South Adriatic were recorded by HURE (1955). During our investigation in the Central Adriatic, neither deep-sea species nor deep mesopelagic species were found, which could be related to the dynamics of water masses and the circulation pattern in the Adriatic Sea. Occasionally, deep-sea bottom water diffuses towards the South Adriatic (ORLIĆ et al., 1992; CUSHMAN-ROISIN \& POULAIN, 2001), forming a barrier for the ostracod species, and thus preventing their migration into the Central Adriatic. That can be the main reason why no ostracod species were found in the greatest depths of the Jabuka Pit as typically found at the same depths in the South Adriatic Pit.
Due to the abundance and frequency of occurrence in the samples, we selected Archiconchoecia striata as the key species. It is an open-sea resident concentrated mainly in the deep epipelagic zone (LEVEAU, 1965). SCHWEIGER (1912) first reported this species from the Central Adriatic Jabuka Pit. GAMULIN (1948) found A. striata only in the deep layer of Jabuka Pit. Recently, the species was also found between 50-300 $\mathrm{m}$ in the South Adriatic (BRAUTOVIĆ, 1998).

During our investigation, Paraconchoecia oblonga was recorded for the first time in the Adriatic Sea. According to ANGEL (1993), this species is widespread in all oceans from $49^{\circ} \mathrm{N}$ to $42^{\circ} \mathrm{S}$ in the shallow mesopelagic layer. The original description is based on material collected from two stations in the North Atlantic Ocean. One of the most important characteristics of P. oblonga is the location of the aperture of the right asymmetric gland; in form A, the gland is situated in the postero-ventral corner of the shell, and in form B the gland opens a little more anteriorly (ANGEL, 1993). Specimens found in the Adriatic Sea belong to form A that is more abundant in the Eastern Atlantic, whereas form B predominates in the Western Atlantic (NIGRO, et al., 2016). Although COI gene sequence divergence (average 0.138 ) suggests that these two forms are separate species (NIGRO et al., 2016), temporary names Paraconchoecia oblonga form $A$ and form B are still in use (WoRMS on-line information system).

\section{Comparisons of planktonic ostracod diversity in various marine regions}

Based on the available past and recent published materials, the Adriatic Sea is rich in ostracod species compared to other Mediterranean regions. In the Tyrrhenian Sea, 11 ostracod species and a new subspecies, Proceroecia procera mediterranea, were found in the vicinity of the islands of Panarea and Stromboli (FERRARI et al., 1995). In general, there are great similarities between the Tyrrhenian and Ionian ostracod community on the one hand, and the South Adriatic ostracod community on the other. 
However, instead of Proceroecia microprocera and $P$. macroprocera that were common in the Adriatic Sea, the Italian researchers found Proceroecia procera procera and Proceroecia procera mediterranea (FERRARI et al., 1995). Although they have not found Porroecia porrecta, the subspecies Porroecia porrecta adriatica was recorded. In addition, they registered Metaconchoecia nasotuberculata, which was not found in the Adriatic Sea. The list of ostracod species of the Tyrrhenian and Ionian seas was later amended with Discoconchoecia elegans gracilis, Mikroconchoecia echinulata and Loricoecia ctenophora (FERRARI et al., 1996). Discoconchoecia elegans, Mikroconchoecia echinulata and Loricoecia loricata were recorded in the Adriatic Sea by BRAUTOVIĆ (1998).

MORAITOU-APOSTOLOPOULOU (1981) elaborately described zooplankton material collected by horizontal and vertical hauls using a $200 \mu \mathrm{m}$ mesh size plankton net in the period from 1964 to 1973 in the Ionian and Aegean Seas, and in the Gulf of Athens. In the Aegean Sea, this author found seven species of planktonic ostracods: $P$. spinirostris, P. procera, Orthoconchoecia haddoni, M. curta, C. magna, D. elegans and A. striata. Among them, only the large mesopelagic species $O$. haddoni (female length $2.7-3.1 \mathrm{~mm}$, males 2.3-2.6 mm) was not found in the Adriatic Sea. Recently, STĘPIEŃ et al. (2015) published a re-description of Discoconchoecia elegans from high latitudes in the North Atlantic.

Planktonic ostracods are usually more abundant in the oceans than in the land-locked Mediterranean and Adriatic Seas. The number of species for the subtropical North-western Atlantic Ocean is estimated at 118 , including 13 new species, while for the whole Atlantic Ocean the number of species is estimated at 153 , which is more than double the number of species known from comparable latitudes in the Pacific Ocean (ANGEL, 2010).

Among 26 species recorded in the mixed layer of the North-eastern Arabian Sea (Indian Ocean), Cypridina dentata, Euconchoecia aculeata, Conchoecia subarcuata and Orthoconchoecia atlantica are dominant during summer monsoon (PURUSHOTHAMAN, 2015). Forty-one (41) spe- cies belonging to the family Halocyprididae have been described by DRAPUN \& SMITH (2012), in the North-western Arabian Sea. Sixteen (16) species of halocyprid ostracods have been identified in the Humboldt Current ecosystem off Peru (CASTILlO et al., 2007).

\section{Relationships within the mesozooplankton community}

On the spatial and temporal scale, distribution patterns of planktonic ostracods can be related to their feeding preferences. Considerably higher abundances of ostracods in deep waters are linked to their detritivorous and carnivorous diet (ANGEL, 1970; RAYMONT, 1983). LOCHHEAD (1968) was the first to record the active predation of planktonic ostracods. Ostracods also represent a suitable prey for mesopelagic and epipelagic chaetognaths Sagitta enflata and S. decipiens, constituting between $1.4 \%$ and $10 \%$ of their diet (BATISTIĆ et al., 2003). For some calycophoran species of siphonophores (e.g. Diphyes dispar and Chelophyes appendiculata), ostracods are just an occasional prey, while others such as Hippopodius hippopus feed exclusively on ostracods (ANGEL, 1983). According to GAMULIN \& KRŠINIĆ (1999), calycophoran siphonophores significantly contribute to the hydrozoan fauna of the Adriatic Sea. This predator-prey link could explain a significant correlation found between ostracods and both siphonophores and chaetognaths $(p<0.01)$. Still, omnivorous feeding or unknown feeding preferences for some ostracod species discourage the generalization of predator-prey relationships within the zooplankton community. Similar variability of different mesozooplankton groups can also indicate high co-linearity (ostracods with copepods, appendicularians and thaliaceans) within the mesozooplankton community.

In comparison to the general distribution pattern of copepod group, distribution of planktonic ostracods was quite opposite. In general, ostracod abundances increase from the North to the South Adriatic. Conversely, copepod abundances mostly increase from the south to the North Adriatic, especially along the continental 
shelf due to the increase of neritic-estuarine species (HURE \& KRŠINIĆ, 1998).

According to study of PANCUCCIPAPADOPOULOU et al., (1992) conducted in the eastern Mediterranean Sea, ostracods were the second most abundant zooplankton group after copepods (62.33\%), constituting 26.98\% of total zooplankton abundance in the southern sea of Rhodes between 150 and $550 \mathrm{~m}$. During our study, the highest proportion of ostracods was noted in autumn in the Central and South Adriatic $(2.2 \%$ and $1.8 \%$ of total zooplankton, respectively). This considerably reduced percentage in comparison to the Eastern Mediterranean Sea was probably influenced by the sampling methodology (i.e. integrated vertical hauls). Due to uneven vertical distribution and a tendency to concentrate in mesopelagic and bathypelagic layers, ostracods should be sampled accordingly, using opening-closing nets in distinct layers.

The results of this study indicate that future planktonic ostracod investigations should focus on the deep South Adriatic. More frequent sampling, using a WP2 net equipped with a closing system, as well as the "Adriatic" sampler designed by KRŠINIĆ (1990), would provide better insight into the vertical distribution pattern and ecology of planktonic ostracods. Considering the complexity of species identification and lack of expert taxonomists, DNA barcoding will be particularly useful in future studies of the ostracod community.

\section{CONCLUSIONS}

In comparison to other Mediterranean regions, the Adriatic Sea is rich in ostracod species. During the investigated period, the key species responsible for most of the observed variability in ostracod abundances were Archiconchoecia striata, Porroecia spinirostris and Proceroecia macroprocera. Paraconchoecia oblonga, form A, was recorded for the first time in the Adriatic Sea, confined exclusively to the southern sub-basin. In general, ostracod abundances and species richness increased from the North to the South Adriatic and their spatial distribution was highly affected by the basin hydrology. At basin level, no clear seasonal pattern of ostracod variability was recorded. However, the observed increase in the number of juveniles indicated autumn and winter as reproduction periods. Taxonomic composition, species richness and distribution patterns of the ostracod community, point to the Central and especially South Adriatic as the areas of particular interest for future investigations of ostracod ecology.

\section{ACKNOWLEDGEMENTS}

We are deeply grateful to Professor Martin V. ANGEL for assistance in taxonomical determination of ostracod species and helpful comments. Thanks are also due to Professor Frano KRŠINIĆ for help and useful suggestions during the preparation of the manuscript. We acknowledge the efforts of two anonymous reviewers whose comments and suggestions greatly improved the manuscript.

This research was supported by the Croatian Science Foundation as a part of research projects IP-2014-09-3606 "Marine plankton as a tool for assessment of climate and anthropogenic influence on the marine ecosystem" (MARIPLAN) and IP-2014-09-4143 "Marine microbial food web processes in global warming perspective" (MICROGLOB). 


\section{REFERENCES}

ANGEL, M.V. 1970. Observations on the behaviour of Conchoecia spinirostris. J. Mar. Biol. Assoc. U.K., 50: 731-736.

ANGEL, M.V. 1983. A review on the progress of research on halocyprid and other oceanic planktonic ostracods 1972-82. In: R.F. Maddocks (Editor). Applications of Ostracoda. University of Houston Geoscience Department, Houston Texas, pp. 529-548.

ANGEL, M.V. 1993. Marine planktonic ostracods. In: D.M. Kermack, R.S.K. Barnes and J.H. Crothers (Editors). Synopsis of the British fauna. 48. Linnean Society of London and The Estuarine and Coastal Sciences Association by the Field Studies Council. Shrewsbury, New Series, pp. 1-239.

ANGEL, M.V. 2010. Towards a full inventory of planktonic Ostracoda (Crustacea) for the subtropical Northwestern Atlantic Ocean. Deep-Sea Res. II, 57: 2173-2188.

ANGEL, M.V., K. BLACHOWIAK-SAMOLYK, I. DRAPUN \& R. CASTILLO. 2007. Changes in the composition of planktonic ostracod populations across a range of latitudes in the Northeast Atlantic. Prog. Oceanogr., 73: 60-78.

BATISTIĆ, M., J. MIKUŠ \& J. NJIRE. 2003. Chaetognaths in the South Adriatic: vertical distribution and feeding. J. Mar. Biol. Assoc. U.K., 83: 1301-1306.

BRAUTOVIĆ, I. 1998. Planktonic ostracods of the South Adriatic Basin. Rapp. Comm. Int. Mer Médit., 35: 384-385.

BRAUTOVIĆ, I., N. BOJANIĆ, M. BATISTIĆ \& M. CARIĆ. 2006. Annual variability of planktonic ostracods (Crustacea) in the South Adriatic Sea. Mar. Ecol. P. S. Z. N. I., 27: 124-132.

CASTILLO, R., T. ANTEZANA \& P. AYON. 2007. The influence of El Nino 1997-1998 on pelagic ostracods in the Humbolt Current ecosystem off Peru. Hydrobiologia, 585: 29-41.

CHAVTUR, V.G. \& G.G. STOVBUN. 2003. Revision of pelagic ostracods of the subfamily Archiconchoecinae. Publ. Seto Mar. Biol. Lab., 39: 139-219.

CHAVTUR, V.G. \& M.V. ANGEL. 2011. Revision of Metaconchoecia (Ostracoda: Halocyprididae) and the designation of two new tribes Conchoeciini and Metaconchoeciini. Zootaxa, 2857: 1-87.

CIVITARESE, G. \& M. GAČIĆ. 2001. Had the eastern Mediterranean transient an impact on the new production in the southern Adriatic. Geophys. Res. Lett., 28: 1627-1630.

CLARKE, K.R. \& R.N. GORLEY 2001. PRIMER v.5 User Manual/Tutorial. In: K.R. CLARKE \& R.N. GORLEY (Editors). PRIMER-E. Plymouth.

CLAUS, C. 1891. Die Halocypriden des Atlantischen Oceans und Mittelmeeres. (The Halocyprida of the Atlantic Ocean and Mediterranean). Arb. Zool. Inst. Wien, 4: 1-82.

CUSHMAN-ROISIN, B. \& P.M. POULAIN. 2001. Circulation. In: B. Cushman-Roisin, M. Gačić, P.M. Pulain and A. Artegiani (Editors). Physical oceanography of the Adriatic Sea. Dordrecht: Kluwer Academic Publishers, pp. 67-109.

DRAPUN, I. \& S.L. SMITH. 2012. Halocyprid Ostracods of the Arabian Sea Region. In:I. Drapun \& S.L. Smith (Editors). Sultan Qaboos University, Academic Publication Press, pp. 1- 223.

FERRARI, I., G. BENASSI, S. SEI, M.V. ANGEL \& K. McKENZIE. 1995. Mediterranean planktonic Ostracoda in Italian waters, off the Islands of Panarea and Stromboli. In: F.M. Faranda (Editor). Caratterizzazione ambientale marina del sistema Eolie e dei bacini limitrofi di Cefal e Gioia (ECOCUMM94). Data Report, pp. 199-222.

FERRARI, I., K. McKENZIE, G. BENASSI, S. SEI, \& M.C. MAGNANI. 1996. New data on planktonic Ostracoda from the Southern Waters (Tyrrenian Sea, Ionian Sea). In: F.M. Faranda and P. Povero (Editors). Caratterizzazione ambientale marina del sistema Eolie e dei bacini limitrofi di Cefalù e Gioia (EOCUMM95). Data Report, pp. 255-296.

FONDA UMANI, S., P. FRANCO, E. GHIRARDELLI, \& A. MALEJ. 1992. Outline of oceanography and the plankton of the Adriatic Sea. In: G. Colombo et al., (Editors). Marine eutrophication and population dynamics. Proceedings 
of the $25^{\text {th }}$ EMBS, Ferarra, Italy. Olsen \& Olsen Publishers, Fredenborg, Denmark, pp 347-365.

GAČIĆ, M., G. CIVITARESE, S. MISEROCCHI, V. CARDIN, A. CRISE \& E. MAURI. 2002. The open ocean convection in the Southern Adriatic: a controlling mechanism of the spring phytoplankton bloom. Cont. Shelf Res., 22: 1897-1908.

GAMULIN, T. 1948. Contribution to the knowledge of zooplankton of the Central Dalmatian island area (In Croatian). Acta Adriat., 3: 1-38.

GAMULIN, T. 1982a. Siphonophora-Calycophorea. In: Z. Vučak (Editor). "A. Mohorovičić" 1974-1976 Reports and results of the oceanographic investigations in the Adriatic Sea. Split, pp. 183-188.

GAMULIN, T. 1982b. Chaetognatha. In: Z. Vučak (Editor). "A. Mohorovičić" 1974-1976 Reports and results of the oceanographic investigations in the Adriatic Sea. Split, pp. 207-210.

GAMULIN, T. \& F. KRŠINIĆ. 1999. Calycophores (Siphonophora, Calycophorae) of the Adriatic and Mediterranean Seas. Nat. Croat., 9: 1-198.

GOODAY, A.J. \& M.V. ANGEL. 1977. Distribution of planktonic Ostracoda (Halocyprididae) in the North Adriatic with the description of a new subspecies Conchoecia porrecta adriatica. Crustaceana, 32: 139-154.

GOLLASCH, S. 1997. Planktonic ostracods (Crustacea) along the coasts of the South Shetland Islands King George and Elephant (Antarctic Ocean) during spring season 1994. Polar Biol., 18: 223-226.

GRANATA, L. \& L. DI CARPORIACCO (Editors). 1949. Ostracodes marines recueillis pendant les croisieres du Prince Albert $1^{\text {er }}$ (Marine ostracods collected during Prince Albert $1^{\text {st }}$ cruises). In: L. Granata, \& L. Di Carporiacco (Editors). Resultats Campagnes Scientifiques du Prince Albert $1^{\text {er }}$ de Monaco 1889-1950, 109: 1-51.

HURE, J. 1955. Distribution annuelle verticale du zooplancton sur une station del'Adriatique méridionale. Acta Adriat., 7: 3-69.
HURE, J. 1961. Diel migration and seasonal vertical distribution of deep sea zooplankton. (In Croatian) Acta Adriat., 9: 1-59.

HURE, J. 1982. Copepoda. In: Z. Vučak (Editor). “A. Mohorovičić" 1974-1976 Reports and results of the oceanographic investigations in the Adriatic Sea. Split, pp. 189-202.

HURE, J. \& F. KRŠINIĆ. 1998. Planktonic copepods of the Adriatic Sea. Spatial and temporal distribution. Nat. Croat., 7: 1-135.

JASPRICA, N., M. CARIĆ \& D. VILIČIĆ. 2001. Relationships of subsurface chlorophyll maximum to diatoms and other microphytoplankton in the southern Adriatic Sea. In: A. Economou Amilli (Editor). Proceedings of the 16th International Diatom Symposium. Athens, pp. 365-379.

KATAVIĆ, I. 1982. Thaliacea. In: Z. Vučak (Editor). “A. Mohorovičić" 1974-1976 Reports and results of the oceanographic investigations in the Adriatic Sea. Split, pp. 217-220.

KRŠINIĆ, F. 1990. A new type of zooplankton sampler. J. Plankton Res., 12: 337-343.

KRŠINIĆ, F. 1998. Vertical distribution of protozoan and microcopepod communities in the South Adriatic Pit. J. Plankton Res., 20: 1033-1060.

KRŠINIĆ, F. \& B. GRBEC. 2002. Some distributional characteristics of small zooplankton at two stations in the Otranto Strait (Eastern Mediterranean). Hydrobiologia, 482: 119136.

KRŠINIĆ, F. \& B. GRBEC. 2006. Horizontal distribution of tintinnids in the open waters of the South Adriatic (Eastern Mediterranean). Sci. Mar., 70: 77-88.

LEVEAU, M. 1965. Contribution a l'étude des ostracodes et cladocères du golfe de Marseille (Contribution to the study of ostracods and cladocerans of the gulf of Marseille). Rec. Trav. St. Mar. End. Bull., 37, 161-246.

LOCHHEAD, J.H. 1968. The feeding and swimming of Conchoecia (Crustacea, Ostracoda). Biol. Bull. Mar. Biol. Lab. Woods Hole, 134: 456-464.

MORAITOU-APOSTOLOPOULOU, M. 1981. Planktonic ostracods collected between 1964 and 1973 from different Greek Sea areas. Vie 
Et Milieu, 31: 171-176.

MÜLLER, G.W. 1912. Ostracoda. In: F.E. Schulze

(Editor). Das Tierreich. Königl. Preuss. Akademie der Wissenschaften zu Berlin, 31: $1-434$

NIGRO, L.M., M.V. ANGEL, K. BLACHOWIAKSAMOLYK, R.R. HOPCROFT \& A. BUCKLIN. 2016. Identification, discrimination, and discovery of species of marine planktonic ostracods using DNA barcodes. PLoS ONE, 11, e0146327. doi:10.1371/journal. pone. 0146327 .

ORLIĆ, M., M. GAČIĆ \& P.E. LA VIOLETTE. 1992.

The currents and circulation of the Adriatic Sea. Oceanol. Acta, 15: 109-124.

PANCUCCI-PAPADOPOULOU, M.A., I. SIOKOUFRANGOU, A. THEOCHARIS, \& D. GEORGOPOULOS. 1992. Zooplankton vertical distribution in relation to the hydrology in the NW Levantine and the SE Aegean seas (spring 1986). Oceanol. Acta, 15: 365-381.

POULSEN, E.M. 1973. Ostracoda-Myodocopa.

Part III B Halocypriformes, Halocypridae, Conchoecinae. Dana Rep, 84: 1-224

PURUSHOTHAMAN, J. 2015. Diversity of planktonic Ostracods (Crustacea: Ostracoda) in the mixed layer of north-eastern Arabian Sea during the summer monsoon. J. Threat. Taxa, 7: 6980-6986.

RAUPACH, M.J. \& A.E. RADULOVICI. 2015. Looking back on a decade of barcoding crustaceans. ZooKeys, 539: 53-81.

RAYMONT, J.E.G. 1983. Plankton and productivity in the oceans. Vol.2. Zooplankton. Pergamon Press, Oxford, pp. 1-824.

REVElante, N. \& M. GILMARTIN. 1977. The effects of northern Italian rivers and eastern Mediterranean ingression on the phytoplankton of the Adriatic Sea. Hydrobiologia 56, 229-240.

SCHWEIGER, L. 1912. Adriatische Cladoceren und Plankton-Ostracoden (Adriatic cladocerans and planktonic ostracods). Sitzungsber. Kaiserl. Akad. Wiss. Wien, Math.-Naturwiss. Cl., 121: 239-272.

SKARAMUCA, B. 1982. Appendicularia (Copelata). In: Z. Vučak (Editor). "A. Mohorovičić" 1974-1976 Reports and results of the oceano- graphic investigations in the Adriatic Sea. Split, pp. 211-216.

SKOGSBERG, T. 1920. Studies on marine Ostracods. Pt I (Cypridinids, Halocyprids and Polycopids). Zool. Bidr. Uppsala, Suppl.

1, pp. 1-784.

SMODLAKA, N. 1982. Chlorophyll $a$. In: Z. Vučak (Editor). "A. Mohorovičić” 1974-1976 Reports and results of the oceanographic investigations in the Adriatic Sea. Split, pp. 221-228.

STĘPIEŃ, A., K. BŁACHOWIAK-SAMOŁYK \& M.V. ANGEL. 2015. A re-description of Discoconchoecia elegans (Sars, 1865) (Ostracoda: Halocyprididae) from high latitudes in the North Atlantic. Zootaxa, 3995: 66-77.

STEUER, A. 1910. Planktonkunde. In: B.G. Teubner (Editor). Leipzig und Berlin, 723 pp.

ŠIPOŠ, V. 1982. Euphausiacea. In: Z. Vučak, (Editor). "A. Mohorovičić" 1974-1976 Reports and results of the oceanographic investigations in the Adriatic Sea. Split, pp. 203-206.

TANAKA, H. \& S. OHTSUKA. 2016. Historical biogeography of the genus Polycopissa (Ostracoda: Myodocopa: Cladocopina), with the description and DNA barcode of the second Indo-Pacific species from the Seto Inland Sea. Mar. Biodiv., 46: 625-640.

TER BRAAK, C.J.F. \& P. ŠMILAUER (Editors). 2012. Canoco reference manual and user's guide: software for ordination, version 5.0., Microcomputer Power, Ithaca, USA, pp. 496. VILIBIĆ, I. \& M. ORLIĆ. 2001. Least-squares tracer analysis of water masses in the South Adriatic (1967-1990). Deep-Sea Res. I, 48: 2297-2330.

VILIČIĆ, D. 2003. Phytoplankton in marine ecosystem (In Croatian). Školska knjiga, Zagreb, pp. 1-196.

VILIČIĆ, D., Z. VUČAK, A. ŠKRIVANIĆ \& Z. GRŽETIĆ. 1998. Phytoplankton blooms in the oligotrophic open south Adriatic waters. Mar. Chem., 28: 89-107.

VILIČIĆ, D., I. MARASOVIĆ \& D. MIOKOVIĆ. 2002. Checklist of phytoplankton in the eastern Adriatic Sea. Acta Bot. Croat., 61: 57-91. 
VILIČIĆ, D., T. ĐAKOVAC, Z. BURIĆ \& S. BOSAK. 2009. Composition and annual cycle of phytoplankton assemblages in the north-eastern Adriatic Sea. Bot. Mar., 52: 291-305.

VUČAK, Z., A. ŠKRIVANIĆ, J. ŠTIRN. et al. 1982. Basic physical, chemical and biological parameters. In: Z. Vučak (Editor). "A. Mohorovičić" 1974-1976 Reports and results of the oceanographic investigations in the Adriatic Sea. Split, pp. 35-175.
WoRMS EDITORIAL BOARD. 2017. World Register of Marine Species. Available from http://www.marinespecies.org at VLIZ. doi: $10.14284 / 170$

ZAVATARELLY, M., F. RAICICH, D. BREGANT, A. RUSSO \& A. ARTEGIANI. 1998. Climatological biochemical characteristics of the Adriatic Sea. J. Mar. System, 18: 227-263.

ZORE-ARMANDA, M. 1963. Les masses d'eau de la Mer Adriatique. Acta Adriat., 10: 1-90.

Received: 9 November 2017

Accepted: 22 March 2018 


\title{
Sastav i raspodjela planktonskih ljuskara (Crustacea, Ostracoda) u Jadranskom moru - povijesna perspektiva
}

\author{
Igor BRAUTOVIĆ, Natalia BOJANIĆ*, Olja VIDJAK, Branka GRBEC \\ i Barbara GANGAI ZOVKO \\ *e-pošta: bojanic@izor.hr
}

\begin{abstract}
SAŽETAK
Rad donosi prve sveobuhvatne rezultate o taksonomskom sastavu vrsta, sezonskoj i horizontalnoj raspodjeli zajednice planktonskih ljuskara u otvorenim vodama cijelog Jadranskog mora. Uzorci su prikupljeni tijekom oceanografske ekspedicije “Andrija Mohorovičić” (1974.-1976.) tijekom četiri godišnja doba na 35 postaja, raspoređenih u osam poprečnih transekata na sjevernom, srednjem i južnom dijelu Jadranskog mora. Taksonomski je određeno petnaest vrsta i dvije podvrste planktonskih ljuskara iz porodice Halocyprididae. Dominantne su vrste bile: Archiconchoecia striata, Porroecia spinirostris i Proceroecia macroprocera. Pored toga, vrsta Paraconchoecia oblonga je po prvi put zabilježena u Jadranskom moru. Najveća abundancija i bio-raznolikost ljuskara je zabilježena u dubokom južnom Jadranu, dok su bili rijetki u plitkom području sjevernog Jadrana. Kao prijelaznu zonu između ova dva područja, srednji Jadran karakterizira velika bio-raznolikost i kratkotrajna dominacija planktonskih ljuskara u zooplanktonskoj zajednici. Njihova horizontalna raspodjela u Jadranskom moru može se povezati s periodičnom ingresijom istočno-mediteranske vode i vrtložnim strujanjima, posebice u područjima srednjeg i južnog Jadrana.
\end{abstract}

Ključne riječi: Halocyprididae, planktonski ljuskari, sastav zajednice, distribucijski obrazac, Jadransko more 